\title{
Penerapan Pembelajaran Berbasis Masalah (Problem Based Learning) untuk Meningkatkan Prestasi dan Kemandirian Belajar Siswa pada Mata Pelajaran PKWU di Kelas Xii IPS, Semester 1 Tahun Pelajaran 2019/2020
}

\author{
Sihono Setyo Budi \\ MAN Wates I Kabupaten Kulon Progo \\ sihonosetyobudi@yahoo.co.id
}

\begin{abstract}
This research in aimed to find out if Problem Based Learning Model can improve the independence of learning and learning achievment at class XII IPS ${ }_{2}$ in MAN 1 Kulon Progo. The subject of this reasearch the students of MAN 1 Kulon Progo at class XII IPS $S_{2}$ for 33 students. The datum are obtained by using observation sheet and quantitative and qualitative data analysis. It is shown that the are significant improvemens on cycle I, cycle II, and cycle III. The everage scores of learning achievement are 65,7 on cycle I, 71,6 on cycle II and 73,5 on cycle III. The evarega score of independence of learning are 73,06, on cycle I, 76,51 on cycle II and 88,18 on cycle III.
\end{abstract}

Keywords: Problem Based Learning Model, Learning Achievement, independence of learning,

\begin{abstract}
Abstrak
Penelitian ini betujuan untuk mengetahui apakah Model Problem Based Learning (PBL) dapat meningkatkan prestasi dan kemandirian belajar siswa di kelas XII IPS, MAN 1 Kulon progo. Subyek penelitian ini adalah siswa MAN 1 Kulon Progo kelas XII IPS, sebanyak 33 siswa. Data diperoleh dengan menggunakan lembar observasi, analisa data menggunakan kuantitatif dan kualitatif. Dari analisa ditemukan bahwa Model Problem Based Learning (PBL) dapat meningkatkan prestasi dan kemandirian belajar siswa. Terlihat terdapat peningkatan yang signifikan antara siklus I, siklus II dan siklus III. Presasi belajar mengalami peningkatan yang signifikan antara siklus I, siklus II dan siklus III. Jumlah skor rata-rata prestasi belajar pada siklus I sebesar 65,7 pada siklus II sebesar 71,6 dan siklus III sebesar 73,5. Jumlah skor ratarata kemandirian belajar siswa juga mengalamai peningkatan, pada siklus I sebesar 73,06 dan pada siklus II sebesar 76,51 dan siklus III sebesar 88,18.
\end{abstract}

Kata Kunci: Model Problem Based Learning, Prestasi belajar, Kemandirian Belajar

\section{PENDAHULUAN}

Pendidikan karakter saat ini menjadi penting mengingat banyak permasalahan bangsa dan negara, kenakalan remaja mulai dari tawuran antar pelajar, penyalahgunaan narkoba, seks bebas yang membuat pendidikan di Indonesia seolah-olah tidak berarti sama sekali bahkan meruntuhkan karakter bangsa.
Data pengawasan KPAI terhadap berbagai kasus kekerasan seksual di dunia pendidikan sepanjang Januari-Juni 2019 di Sekolah Dasar 49 korban dan di Sekolah Menengah Pertama 24 korban. $^{1}$

'https://nasional.tempo diakses tanggal 10 Desember 2019 
Pendidikan karakter dimaknai pendidikan nilai, budi pekerti, moral, yang mempunyai tujuan mengembangkan karakter positif siswa dalam kehidupan sehari-hari. Pendidikan karakter yang diterapkan secara sistematis dan berkelanjutan, diharapkan siswa memiliki karakter positif. Sekolah yang menerapkan pendidikan karakter secara komprehensif menunjukkan adanya penurunan drastis pada perilaku negatif siswa yang dapat menghambat keberhasilan belajar.

Penerapan pendidikan karakter yang terintegrasi dalam mata pelajaran yang ada menjadi urgen dari pada penambahan mata pelajaran pendidikan karakter menjadi pelajaran baru. Dalam mata pelajaran Prakarya dan Kewirausahaan (PKWU) banyak karakter positif yang diperoleh siswa antara lain, sikap mencintai kebenaran, kemandirian, disiplin, gotong royong, teliti, toleransi kreatif dan lainlain.

Pembelajaran Prakarya dan Kewirausahaan (PKWU) yang dilaksanakan seolah-olah mengabaikan makna karakter yang terkandung. Pembelajaran lebih menekankan ranah kognitif dan psikomotorik saja, seperti menjabarkan rumus-rumus dan mengerjakan proyek. Penilaian pun dilakukan pada ranah kognitif dan psikomotorik saja.

Penilaian pada ranah kognitif dan psikomotorik pada mata pelajaran Prakarya dan Kewirausahaan (PKWU) di MAN 1 Kulon progo masih jauh dari harapan, hal ini ditunjukkan peraihan nilai siswa yang belum mencapai ketuntasan belajar minimal (KBM) yaitu $70 .^{2}$ Data menunjukkan dari 33 siswa ada 14 anak yang tidak mencapai nilai KBM, dengan kata lain $42 \%$ belum tuntas. Rendahnya hasil belajar ini disebabkan beberapa hal antara lain pembelajaran Prakarya dan Kewirausahaan (PKWU) belum menyenangkan, belum menarik dan menantang bagi siswa, siswa kurang dilibatkan dalam menemukan konsep, fakta, dan prinsip yang digunakan dalam memecahkan

\footnotetext{
${ }^{2}$ Team kurikulum, Kurikulum KTSP MAN I Wates, tahun 2017/2018
}

masalah. Faktor lainnya yang mempengaruhi prestasi belajar Prakarya dan Kewirausahaan (PKWU) rendah adalah kemandirian siswa. ${ }^{3}$

Kemandirian akan membuat siswa mampu belajar sendiri tanpa disuruh oleh pihak luar dalam kondisi ujian atau tidak ujian. Dengan kemandirian yang tinggi, diharapkan siswa dapat memanfaatkan waktu di sekolah dan di rumah, menggunakan keseluruhan sumber belajar baik sumber belajar tercetak maupun non cetak. Kemandirian siswa menekankan pada aktivitas dalam belajar yang penuh tanggung jawab sehingga mampu mencapai prestasi belajar yang tinggi. Ini sejalan dengan penelitian Budi (2012), menemukan bahwa kemandirian belajar memberikan kontribusi $21,2 \%$ terhadap prestasi belajar. ${ }^{4}$

Pembelajaran dengan problem base learning siswa terlibat secara mental maupun fisik untuk memecahkan masalah yang di berikan guru. Dengan demikian siswa akan bersikap jujur, teliti, kreatif, disiplin dan mandiri serta saling bergotong royong dalam memecahkan masalah. Pembelajaran ini mengandung beberapa aspek antara lain: (1) mengoreintasi siswa pada masalah, (2) mengorganisasi siswa untuk belajar, (3) membimbing siswa dalam penyelidikan, (4) menyajikan karya,(5) mengalisa dan mengevaluasi proses pemecahan masalah. ${ }^{5}$

Dalam pembelajaran di kelas XII IPS peneliti menemukan permasalahan, yaitu kemandirian belajar dan prestasi belajar siswa pada pelajaran Prakarya dan Kewirausahaan (PKWU) rendah. Rendahnya kemandirian

${ }^{3}$ ihono, S dan Rahma, W, Korelasi antara kreativitas belajar, motivasi belajar dan kemandirian belajar siswa dengan prestasi belajar keterampilan elektronika di MAN I Wates Kabupaten Kulon Progo tahun 2012. Jurnal INSIGHT Volume 10, Nomor 1, Februari 2012 (Yogyakarta: Universitas Mercu Buana Yogyakarta.2012)

${ }^{4}$ Budi, S. Korelasi antara kreativitas belajar, motivasi belajar dan kemandirian belajar siswa dengan prestasi belajar keterampilan elektronika di MAN I Wates Kabupaten Kulon Progo tahun 2012. Thesis Yogyakarta: Universitas Mercu Buana Yogyakarta.2012

${ }^{5}$ Rusmono, Strategi pembelajaran dengan Problem Base Learning itu perlu. (Jakarta: Ghalia Indonesia ,2017) hal 82 
belajar dan prestasi belajar ini, disebabkan oleh penggunaan metode pembelajaran yang kurang tepat atau kurang menarik dalam menyampaikan materi. Hal itu berakibat sikap kemandirian belajar siswa yang tidak optimum sehingga berpengaruh juga terhadap prestasi belajar siswa.

Upaya yang dilakukan untuk mengatasi peramasalahan tersebut, seperti melakukan diskusi dan tanya jawab. Namun upaya tersebut belum berhasil dikarenakan siswa yang mau bertanya dan berperan aktif dalam pelajaran hanya beberapa siswa saja, sedangkan siswa yang lain belum. Permasalahan di atas menunjukkan bahwa pembelajaran perlu diperbaiki. Pembenahan pembelajaran antara lain dengan menggunakan suatu model pembelajaran yang mampu meningkatkan kemandirian belajar dan prestasi belajar siswa. Salah satu cara dengan menerapkan Problem Based Learning atau dikenal dengan Pembelajaran Berbasis Masalah. Hal inilah yang mendorong peneliti untuk mengkaji tentang peningkatan kemandirian belajar dan prestasi belajar dengan Problem Based Learning.

Pengajaran berdasarkan masalah artinya pembelajaran didasarkan pada masalah seharihari, dalam pembelajaran siswa diajak untuk memecahkannya. Melalui pembelajaran semacam itu siswa akan merasa ditantang untuk mengajukan gagasan. Biasanya akan muncul berbagai gagasan dan siswa akan saling memberikan alasan dari gagasan yang diajukan. Dalam proses pembahasan, gagasan itu akan terjadi interaksi dan pemaduan gagasan yang pada akhirnya mengarah pada saling melengkapi. Senada dengan hal tersebut, Zulharman (2007), mengemukakan bahwa Problem Based Learning adalah proses pembelajaran yang titik awal pembelajaran berdasarkan masalah dalam kehidupan nyata dan lalu dari masalah ini siswa dirangsang untuk mempelajari masalah ini berdasarkan pengetahuan dan pengalaman yang telah mereka punyai sebelumnya (prior knowledge) sehingga dari prior knowledge ini akan terbentuk pengetahuan dan pengalaman baru. Diskusi dengan menggunakan kelompok kecil merupakan poin utama dalam penerapan pembelajaran berdasarkan masalah. ${ }^{6}$

Belajar berdasarkan masalah diawali dari masalah-masalah yang ditemukan dalam suatu lingkungan sekitar dengan demikian Problem Based Learning (PBL) adalah lingkungan belajar yang di dalamnya menggunakan masalah untuk belajar. Yaitu, sebelum siswa mempelajari suatu hal, mereka diharuskan mengidentifikasi suatu masalah, baik yang dihadapi secara nyata maupun telah kasus. Masalah diajukan sedemikian rupa sehingga siswa menemukan kebutuhan belajar yang diperlukan, dan mereka dapat memecahkan masalah tersebut.

Problem Based Learning (PBL) memusatkan pada masalah kehidupannya yang bermakna bagi siswa, peran guru menyajikan masalah, mengajukan pertanyaan dan memfasilitasi penyelidikan dan dialog. Pengajaran berdasarkan masalah ini merupakan pendekatan yang efektif untuk pengajaran proses berpikir tingkat tinggi. Pembelajaran ini membantu siswa untuk memperoses informasi yang sudah jadi dalam benaknya dan menyusun pengetahuan mereka sendiri tentang dunia sosial dan dan sekitarnya. Pembelajaran ini cocok untuk mengembangkan pengetahuan dasar maupun kompleks.

Ciri utama PBL meliputi mengorientasikan siswa kepada masalah atau pertanyaan yang autentik, multidisiplin, menuntut kerjasama dalam penyelidikan dan menghasilkan karya. Secara terinci ciri PBL adalah sebagai berikut. ${ }^{7}$

Mengorientasikan siswa kepada masalah autentik. Pada tahap ini guru menyusun skenario yang dapat menarik perhatian siswa, sekaligus memunculkan pertanyaan yang benar-benar nyata di lingkungan siswa serta dapat diselidiki

${ }^{6}$ http://alief-hamsa.blogspot.com/2009/08/ perubahan-paradigma-pendidikan-di.html [tersedia online] diakses tanggal 9 Desember 2020.

${ }^{7}$ Budi,S. Penerapan metode problem based instruction (PBL) untuk meningkatkan kemampuan siswa dalam memecahkan masalah keterampilan elektronika di kelas XI IPA1 MAN Wates I Kabupaten Kulon Progo. (Yogyakarta, MAN 1 Kulonprogo ,2012 PTK tidak dipublikasikan) 
oleh siswa kepada masalah yang autentik ini dapat berupa cerita, penyajian fenomena tertentu, atau mendemontrasikan suatu kejadian yang mengundang munculnya permasalahan atau pertanyaan. Mendemonstrasikan kejadiankejadian yang memunculkan konfliks kognitif diyakini sangat baik untuk mengorientasikan siswa kepada masalah ini.

Berfokus pada keterkaitan antar disiplin. Meskipun PBL berpusat pada pelajaran tertentu, misalnya biologi, masalah yang dipilih benarbenar nyata agar dalam pemecahannya, siswa dapat meninjau dari berbagi mata pelajaran yang lain. Sebagai contoh masalah polusi pada contoh di atas, mencakup aspek akademis dan terapan mata pelajaran ekonomi sosiologi, parawisata, dll. Begitu pula pada masalah menyajikan makanan untuk kakek, melibatkan biologi, kesehatan, kimia dan sebagainya. ${ }^{8}$

Penyelidikan autentik. PBL mengharuskan siswa melakukan penyelidikan autentik untuk mencari penyelesaian nyata terhadap masalah nyata. Mereka menganalisis dan mendefinisikan masalah, menyusun hipotesis, mengumpulkan dan menganalisis informasi/data, melakukan percobaan, membuat inferensi dan merumuskan simpulan. Metode yang digunakan sangat bergantung kepada masalah yang sedang dipelajari. ${ }^{9}$

Menghasilkan produk / karya dan memamerkannya. PBL menuntut siswa untuk menghasilkan produk tertentu dalam bentuk karya nyata atau artifak dan memamerkan.

Karya tersebut dapat berupa rekaman debat, laporan, model fisik, video dan program komputer. ${ }^{10}$

${ }^{8}$ Budi,S. Penerapan metode problem based instruction (PBL) untuk meningkatkan kemampuan siswa dalam memecahkan masalah keterampilan elektronika di kelas XI IPA1 MAN Wates I Kabupaten Kulon Progo. (Yogyakarta, MAN 1 Kulonprogo ,2012 PTK tidak dipublikasikan)

${ }^{9}$ Febriana,R \& Sarbiran, Pengaruh kemandirian dan kemampuan menyesuaikan diri terhadap prestasi belajar siswa full day school. Jurnal penelitian dan evaluasi No.4 tahun Ke-3. (Yogyakarta:Pascasarjana Universitas Negeri Yogyakarta.2001

${ }^{10}$ Djamarah, Prestasi Belajar dan Kompetensi Guru
Problem Based Learning (PBL) utamanya dikembangkan untuk membantu siswa mengembangkan kemampuan berpikir, pemecahan masalah dan keterampilan intelektual, belajar berbagi peran orang dewasa dengan melibatkan mereka dalam pengalaman nyata atau simulasi.

Pengajaran berdasarkan masalah dikembangkan untuk membantu siswa mengembangkan kemampuan berpikir, pemecahan masalah, dan ketrampilan intelektual, belajar berbagai peran orang dewasa melalui perlibatan mereka dalam pengalaman nyata atau simulasi, dan menjadi pembelajar yang otonom dan mandiri. Untuk memperoleh kemampuan dalam menganalisa masalah di perlukan pengalaman dalam berbagai pemecahan masalah. Pengalaman akan bisa muncul apabila siswa sering berlatih. Siswa yang diberi banyak latihan pemecahan masalah akan memiliki pengalaman lebih dalam kehidupan sehari-hari. ${ }^{7}$ Suherman (2003), memetakan dalam penyelesaian masalah memuat empat fase penyelesaian yaitu: (1). memahami / mengidentifikasi masalah, (2). merencanakan penyelesaian masalah, (3). menyelesaikan masalah sesuai rencana, (4). melakukan pengecekan kembali terhadap semua langkah yang dikerjakan/ menafsirkan.

Febriana dan Sarbiran (2001) kemandirian belajar adalah kemampuan siswa untuk belajar sendiri tanpa tergantung pada orang lain, mampu mengerjakan tugas rutin secara mandiri, bertanggung jawab atas tindakannya, memiliki kemampuan berinisiatif, mampu mengatasi masalah, percaya diri dan dapat mengambil keputusan dalam bentuk memilih. Siswa yang memiliki kemandirian belajar diharapkan mampu belajar secara aktif baik saat didampingi guru maupun tanpa didampingi guru. Siswa yang mampu belajar mandiri adalah siswa yang dapat mengontrol dirinya sendiri, mempunyai minat dalam mempelajari materi pelajaran, motivasi yang tinggi, yakin akan dirinya, mempunyai orientasi atau wawasan yang luas dan luwes.

(Surabaya: Usaha Nasional 1994 ), hal 19 
Febriana dan Sarbiran (2001), memberikan indikator kemandirian belajar yaitu: (1) mencukupi kebutuhan sendiri, (2) mampu mengerjakan tugas rutin secara mandiri, (3) bertanggungjawab atas tindakannya, (4) memilikinya kemampuan inisiatif, (5) mampu mengatasi masalah, (6) percaya diri, (7) dapat mengambil keputusan dalam bentuk memilih.

Dalam proses belajar mengajar bidang studi Prakarya dan Kewirausahaan (PKWU) di MAN 1 Kulon Progo, kemandirian belajar sangat menetukan prestasi belajar. Sebaikbaiknya metode yang digunakan guru, jika kemandirian belajar siswa kurang maka siswa. tidak akan belajar dengan baik, mengakibatkan prestasi belajarnya tidak baik pula

Penggunaan metode yang tepat akan berpengaruh terhadap kemandirian belajar siswa yang akirnya akan meningkat pula prestasi belajarnya. Prestasi belajar merupakan hal yang tidak dapat dipisahkan dari kegiatan belajar, karena kegiatan belajar merupakan proses, sedangkan prestasi merupakan hasil dari suatu kegiatan yang telah di kerjakan secara individu atau kelompok

Prakarya dan Kewirausahaan (PKWU) di Madrasah Aliyah bertujuan untuk memberikan bekal keterampilan yang bermanfaat bagi siswa untuk mengembangkan kehidupannya sebagai pribadi, anggota masyarakat dan warga negara, baik secara mandiri, maupun untuk terjun ke dunia kerja sesuai dengan tingkat perkembangannya.

Setelah mengikuti pembelajaran Prakarya dan Kewirausahaan di Pendidikan Dasar dan Menengah diharapkan peserta didik memiliki kompetensi, mulai dari yang bersifat imitasi / meniru (guided response), yaitu meniru gerakan secara terbimbing); manipulatif (membiasakan atau mekanism); dan presisi / mahir (complex or overt response), yaitu melakukan gerakan kompleks dan termodifikasi.

Prestasi belajar siswa dapat diketahui melalui pelaksanaan evaluasi atau assessment, karena dengan cara itulah dapat diketahui tinggi rendahnya prestasi belajar siswa atau baik buruk prestasi belajarnya. Prestasi merupakan hasil dari suatu kegiatan yang telah di kerjakan secara individu atau kelompok. ${ }^{11}$

Penilaian dalam pelajaran Prakarya dan Kewirausahaan (PKWU) menggunakan acuan kriteria. Maksudnya hasil yang dicapai peserta didik dibandingkan dengan kriteria standar yang ditetapkan. Apabila siswa telah mencapai standar kompetensi yang ditetapkan maka siswa dinyatakan lulus dari mata pelajaran demikian sebaliknya. Mengacu pada kriteria minimal yang ditetapkan untuk mata pelajaran Prakarya dan Kewirausahaan (PKWU) di MAN 1 Kulon Progo sebesar 70 ( Kurikulum KTSP MAN 1 Kulon Progo 2018). ${ }^{4}$

\section{METODE PENELITIAN}

Penelitian ini adalah Penelitian Tindakan Kelas (PTK) yang dilakukan secara kolaboratif antara guru mata pelajaran PKWU dan peneliti yang dilaksanakan di Madrasah Aliyah Negeri 1 Kulon Progo (MAN I Kulonprogo). Peran guru mata pelajaran sebagai kolaborator, sedangkan peneliti sebagai pelaksana pembelajaran. Keduanya terlibat sejak perencanaan, pelaksanaaan, pengamatan hingga refleksi terhadap pembelajaran.

Subjek penelitian ini adalah siswa kelas XII IPS2 MAN 1 Kulon Progo tahun pelajaran 2019/2020 sejumlah 33 siswa yang dipandang

\section{HASIL DAN PEMBAHASAN}

Penelitian dilakukan 3 siklus dengan hasil sebagai berikut :

\section{Siklus I}

Pembelajaran pada siklus 1 dilaksanakan selama tiga kali pertemuan dengan kegiatan pengukuran kemandirian, pengukuran pelaksanaan pembelajaran $\mathrm{PBL}$, pengukuran aktivitas belajar siswa dan pengukuran prestasi belajar. Tindakan yang dilakukan pada siklus 1 ini meliputi:

${ }^{11}$ Team kurikulum, Kurikulum KTSP MAN I Wates, tahun 2018 


\section{Perencanaan}

Dari identifikasi masalah saat pelaksanaan pembelajaran peneliti menganalisis dan merumuskan masalah yang selanjutnya akan dicarikan solusinya. Solusi yang digunakan mengubah metoda pembelajaran dengan metode Problem Based Learning (pembelajaran berdasarkan masalah). Pada tahap ini peneliti menyusun perangkat pembelajaran (RPP), Lembar Kegiatan siswa (LKS) dan beberapa instrumen observasi yaitu: instrumen observasi aktivitas siswa, instrumen observasi kemandirian belajar siswa, instrumen penilaian proyek yang mencerminkan prestasi belajar dan instrumen observasi pembelajaran yang digunakan sebagai catatan selama proses belajar mengajar berlangsung.

\section{Pelaksanaan tindakan}

Pelaksanaan pembelajaran pada siklus pertama dilaksanakan selama tiga kali pertemuan yaitu pada tanggal 17, 24 September dan 1 Oktober 2019 dengan durasi 90 menit $(2 \times 45$ menit), dengan materi pembuatan PCB yang meliputi: desain rangkaian, desain alur PCB, pelarutan dan pelobangan PCB. Pembelajaran diawali dengan mengingatkan kembali materi sebelumnya, selanjutnya memberikan motivasi dan menjelaskan cara mendesain rangkaian, mendesain alur Printed Circuit Board (PCB), melarutkan $\mathrm{PCB}$, dan mengebor PCB. Adapun tindakan yang dilakukan oleh adalah: Guru memberikan permasalahan yang esensial berupa penugasan untuk merangsang siswa melakukan aktifitas. Topik yang diberikan adalah desain PCB sensor cahaya. Guru menjelaskan logistik yang diperlukan untuk desain PCB dan permasalahannya. Kemudian membentuk kelompok menjadi enam diberikan lembar kerja siswa (LKS) untuk di kerjakan. Guru mengawasi jalannya kerja kelompok dan observer mengamati sekaligus mencatat aktivitas siswa dalam pembelajaran. Pada awalnya siswa masih mengalami kesulitan dan tidak terkoordinasi dengan baik dalam mengerjakan desain alur PCB sensor cahaya. Guru membimbing cara mendesain PCB yang meliputi: cara membaca rangkaian sensor cahaya, membuat desain alur, melarutkan PCB dan pengeboran. Guru mengajak siswa mengumpulkan berbagai cara pembuatan PCB dan permasalahan yang terjadi, meliputi desain alur, melarutkan PCB, mengebor PCB, dan melapisi PCB. Siswa diajak diskusi tentang permasalahan yang terjadi dalam pembuatan PCB

Selanjutnya siswa diminta merefleksi secara kelompok untuk mengemukakan permasalahan dan pengalamannya selama mengerjakan pembuatan PCB, sehingga di temukan cara pembuatan PCB yang yang lebih efektif.

\section{Tahap Pengamatan}

Pada tahap pegamatan dilaksanakan dengan bantuan teman sejawat (guru PKWU). Hal yang diamati selama proses pembelajaran berlangsung terekam dalam lembar obervasi yang meliputi: keterlaksanaan proses pembelajaran dengan Problem Base Learning, aktivitas belajar siswa, kemandirian siswa dalam mengerjakan tugas dan prestasi siswa. Data penelitian ini dianalisis sejak tindakan pembelajaran dilakukan. Data yang diperoleh dalam penelitian berupa hasil catatan di lapangan dan hasil observasi. Setelah itu dilakukan reduksi data yang bertujuan untuk merangkum, menyerderhanakan memfokuskan, dan mentransfer data. Langkah selanjutnya dilakukan analisis data berupa:

Data observasi pelaksanaan pembelajaran PBL, dianalisis dengan mendiskripsikan pelaksanaan pembelajaran di dalam kelas. dengan kriteria penilaian sebagai berikut: skor 3 bila pelaksanaan pembelajaran baik; skor 2 bila pelaksanaan pembelajaran kurang baik dan skor 1 bila pelaksanaan pembelajaran tidak baik. Cara menghitung skor pelaksanaan pembelajaran adalah sebagai berikut:

Persentase pelaksanaan pembelajaran

$=\frac{\text { jumlah skor }}{\text { Skor maksimum }} \times 100 \%$ 
Tabel 1. Kriteria pelaksanaan pembelajaran (PP)

\begin{tabular}{lc}
\hline $\begin{array}{l}\text { Rentang Persentase } \\
67 \%<\mathrm{PP} \leq 100 \%\end{array}$ & $\begin{array}{c}\text { Kriteria } \\
\text { Baik }\end{array}$ \\
\hline $33 \%<\mathrm{PP} \leq 67 \%$ & Cukup \\
\hline $0 \%<\mathrm{PP} \leq 33 \%$ & Kurang
\end{tabular}

Data observasi aktivitas siswa dianalisis dengan mendiskripsikan kegiatan belajar kelompok dengan menggunakan lembar observasi aktivitas siswa dengan aspek sebagai berikut: bertanya pada guru, aktif berdiskusi memecahkan masalah, aktif dalam memahami soal, aktif merencanakan pemecahan soal, aktif melaksanakan rencana, aktif dalam menafsirkan hasil, dengan ketentuan : skor 1 tidak ada siswa yang melaksanakan aktivitas, skor 2 siswa yang melaksanakan aktivitas 1- 2 orang, skor 3 siswa yang melaksanakan aktivitas 3-4 orang, skor 4 siswa yang melaksanakan aktivitas 5 - 6 orang. Penilaian dapat dilihat dari hasil skor pada lembar observasi, persentase skor diperoleh pada lembar observasi untuk menentukan besar aktivitas siswa dalam mengikuti proses pembelajaran. Untuk setiap siklus persentase diperoleh dengan rerata persentase keaktifan siswa pada tiap pertemuan pembelajaran berkelompok. Formulasi persentase banyaknya siswa yang aktif dalam pemecahan masalah keterampilan elektronika $(\mathrm{Pk})$ adalah:

$=\frac{\text { jumlah skor }}{\text { jumlah kelompok x skor maksimum X jumlah aspek }} \times 100 \%$

Dengan kriteria sebagai berikut:

Tabel 2. Persentase banyaknya siswa yang aktif dalam pemecahan masalah

\begin{tabular}{ll}
\hline Rentang Persentase & Kriteria \\
\hline $80<\mathrm{SA} \leq 100$ & Sangat Baik \\
$60<\mathrm{SA} \leq 80$ & Baik \\
$40<\mathrm{SA} \leq 60$ & Cukup \\
$20<\mathrm{SA} \leq 40$ & Kurang \\
$0<\mathrm{SA} \leq 20$ & Sangat Kurang \\
\hline
\end{tabular}

Data karakter mandiri belajar siswa, untuk mengukur peningkatan karakter mandiri belajar siswa dilaksanakan setiap akhir siklus.Pada setiap pengukuran menghasilkan skor karakter mandiri belajar siswa dalam mengerjakan tugas, dengan skor maksimal 7. Pemberian skor karakter mandiri belajar siswa didasarkan pada pendapat Febriana dan Sarbiran (2001), dengan indikator: (1) mencukupi kebutuhan sendiri, (2) mampu mengerjakan tugas rutin secara mandiri, (3) bertanggungjawab atas tindakannya, (4) memilikinya kemampuan inisiatif, (5) mampu mengatasi masalah, (6) percaya diri, (7) dapat mengambil keputusan dalam bentuk memilih.

Kemudian diperoleh jumlah skor, dan ditentukkan skor rerata tiap siklus dengan menjumlahkan semua skor siswa kemudian membaginya dengan jumlah siswa.

$$
\text { Formula }=\frac{\text { jumlah skor seluruh siswa }}{\text { jumlah siswa }}
$$

Kriteria skor karakter mandiri belajar siswa dalam mengerjakan tugas sebagai berikut:

Tabel 3. Kriteria karakter mandiri (KM) dalam belajar belajar

\begin{tabular}{ll}
\hline rentang nilai Mandiri & kriteria \\
\hline $81<\mathrm{KM} \leq 100$ & sangat baik \\
$61<\mathrm{KM} \leq 80$ & baik \\
$41<\mathrm{KM} \leq 60$ & cukup \\
$21<\mathrm{KM} \leq 40$ & kurang \\
$0<\mathrm{KK} \leq 20$ & sangat kurang \\
\hline
\end{tabular}

Data prestasi belajar, dianalisis dengan mendeskripsikan kegiatan belajar yang telah dilakukan siswa dengan menggunakan soal tes praktek. Data prestasi belajar berupa penilaian tugas praktek, dianalisis dengan mendeskripsikan kegiatan belajar yang telah dilakukan siswa dengan aspek sebagai berikut: (a) tahap perencanaan, (b) tahap proses meliputi: (1) persiapan alat dan bahan, (2) teknik pembuatan, (3) K3 dan tahap akhir meliputi: (1) bentuk fisik, dan (2) inovasi. Cara menghitung rerata skor penilaian praktek adalah sebagai berikut:

$$
\text { Rerata }=\frac{\text { jumlah skor }}{\text { jumlah siswa }}
$$
berikut : 
Tabel 4. Kriteria Prestasi Belajar (PB)

\begin{tabular}{ll}
\hline Rerata Skor & Kriteria \\
\hline $80<\mathrm{PB} \leq 100$ & sangat baik \\
$60<\mathrm{PB} \leq 80$ & baik \\
$40<\mathrm{PB} \leq 60$ & cukup \\
$20<\mathrm{PB} \leq 40$ & kurang \\
$0<\mathrm{KPP} \leq 20$ & sangat kurang \\
\hline
\end{tabular}

Langkah selanjutnya dilakukan analisis data berupa:

Hasil pengamatan sebagai berikut:

Data observasi pelaksanaan pembelajaran dengan problem base learning terdapat dua indikator dengan kategori cukup dan lima indikator kategori baik sehingga skor total $=$ $(2 \times 2)+(5 X 3)=19$ bila skor maksimal 21 maka prosentasenya sebesar $(19 / 21) \times 100 \%=90,4$ $\%$. Dengan melihat tabel 1. maka pelaksanaan pembelajaran kategori baik.

Jumlah skor kemandirin belajar seluruh siswa 2378, jumlah siswa 33 orang maka rerata $=(2378 / 33)=73,06$. berdasarkan tabel 3. rerata kemandirian belajar kategori baik.

Skor setiap indikator dari enam kelompok: $12,16,19,18,17$, dan 18. Jumlah skor $=100$, jumlah kelompok 6, skor maksimal 4. Rerata persentase skor aktivitas belajar siswa dalam mengerjakan permasalahan adalah $=\frac{100}{6 \times 4 \times 6} \mathrm{X}$ $100 \%=69 \%$, dengan melihat tabel 2. maka aktivitas belajar siswa kategori baik

Jumlah skor prestasi belajar dari 33 siswa sebesar 2164, maka rerata prestasi belajar $=2164 / 33=65,57$ dengan melihat tabel 4 . kategori baik.

Hasil pada siklus pertama seperti tabel 5.

Tabel 5. Hasil siklus 1

\begin{tabular}{llllll}
\hline Siklus & Persentase & \multicolumn{3}{c}{ Rerata Skor } & \\
\cline { 1 - 4 } 1 & pelaksanaan & aktivitas & Karakter & Prestasi \\
& pembelajaran & belajar & mandiri & belajar & Ket \\
& $90,4 \%$ & $69 \%$ & 73,06 & 65,57 & \\
Kategori & Baik & Baik & Baik & Baik & \\
\hline
\end{tabular}

\section{Refleksi}

Diskusi yang dilakukan peneliti dan observer terhadap pelaksanaan pembelajaran siklus I beberapa hambatan dan kekurangan antara lain: (1) Masih ada siswa yang belum mampu memahami permasalahan yang terdapat dalam Lembar Kerja Siswa (LKS) pembuatan PCB sensor, siswa masih saling menunggu. (2) Masih ada siswa yang belum mampu membuat rencana pemecahan masalah yang terdapat dalam Lembar Kerja Siswa(LKS) pembuatan PCB sensor cahaya. (3) Sebagian siswa dalam mengerjakan tugas dari guru, terutama langkah dalam mendesain alur rangkaian $\mathrm{PCB}$ masih perlu bimbingan yang intensif. (4) Sebagian siswa belum mampu menentukan langkah mendesain alur PCB, sehingga masih perlu bimbinagn guru. (5) Sebagian siswa belum mampu merencanakan waktu dengan tepat sehingga pelaksanaan proyek tidak sesuai waktu yang ditentukan. (6) Sebagian siswa kurang aktif menunggu hasil kerja kawannya bahkan menuggu bantuan guru, peran guru masih sangat dominan. (7) Hasil PCB yang telah dilarutkan masih ada yang belum sesuai dengan stantar ketercapaian, alur dan desain masih kurang, pengeboran, desain belum rapi walaupun dapat berfungsi. (8) Siswa banyak tidak mau bertanya, padahal belum mampu mengerjkan LKS. (9) Siswa masih takut mendiskusikan pengalaman belajarnya kepada teman dan guru. (10) Kemandirian belajar dalam mengerjakan LKS belum optimal ini terlihat banyak siswa yang tergantung temannya. (11) Pelaksanaan pembelajaran dengan PBL secara umum sudah terlaksana tetapi belum optimal.

Guru bersama observer berdiskusi untuk memberikan solusi terhadap permasalahan yang terjadi pada siklus I selanjutnya untuk dilaksanakan pada siklus ke II dengan alternatif sebagai berikut: (1) Siswa diajak untuk memahami permasalahan yang terdapat dalam Lembar Kerja Siswa (LKS) pembuatan PCB sensor sehingga dapat mengerjakan tugas sesuai langkah dalam LKS. (2) Siswa diajak untuk membuat langkah rencana pemecahan masalah yang terdapat dalam Lembar Kerja Siswa (LKS) pembuatan PCB sensor cahaya, meliputi pemahaman soal, merencanakan pemecahan masalah, melaksanakan rencana, dan menafsirkan permasalahan. (3) Siswa yang 
belum mampu mengerjakan tugas, diberikan motivasi dan beberapa contoh desain agar kemandirian belajarnya meningkat. (4) Siswa yang kurang aktif difasilitasi dalam setiap proses, sehingga peran guru sebagai mentor bagi aktivitas siswa. (5) Siswa yang kurang aktif dibimbing secara intensif agar percaya diri sehingga mampu memecahkan masalahnya tanpa bantuan guru. (6) Siswa dirangsang untuk aktif dan mau bertanya dalam mengerjkan LKS. (7) Siswa dirangsang dengan pemberian nilai plus bagi yang mau mendiskusikan pengalaman belajarnya selama mengerjakan proyek pada teman dan guru di depan kelas.

\section{Siklus II}

Rancangan pada siklus II hampir sama dengan siklus I akan tetapi dilakukan perbaikan - perbaikan rencana tindakan. Pada siklus II ini merupakan kelanjutan dari siklus I sampai proyek dapat berfungsi dengan baik. Adapun rencana tindakan yang akan dilaksanakan sebagai berikut:

\section{Perencanaan}

Peneliti menyusun LKS dan instrumen observasi, antara lain: instrumen observasi pembelajaran Problem base learning (PBL), instrumen observasi aktivitas belajar siswa, instrumen kemandirian belajar siswa, instrumen penilaian yang mencerminkan prestasi belajar yang digunakan sebagai catatan selama proses belajar mengajar berlangsung.

\section{Pelaksanaan tindakan dan observasi}

Pelaksanaan pembelajaran pada siklus kedua dilaksanakan pada tanggal 8, 15 dan 22 Oktober 2019 dengan durasi 90 menit (2x45 menit), dengan materi merangkai komponen rangkaian sensor. Pada pertemuan pertama siswa sudah terbiasa dengan situasi kelas yang diamati. Guru memulai pembelajaran dengan mengingatkan kembali materi sebelumnya, selanjutnya memberikan motivasi dan membentuk kelompok menjadi 6 kelompok dengan anggota 6 dan 5 orang, diberikan LKS untuk di kerjakan. Adapun tindakan yang dilakukan adalah: (1) Guru mengawali pelajaran dengan sebuah pertanyaan yang mendasar bagaimana cara mengatasi keruwetan sambungan antar komponen. Siswa diajak untuk memahami permasalahan dalam Lembar Kerja Siswa (LKS) tentang pemasangan komponen pada PCB sensor sehingga dapat mengerjakan tugas sesuai langkahnya. (2) Siswa diarahkan bekerja secara kolaboratif merencanakan pemecahan masalah dalam Lembar Kerja Siswa (LKS) tentang pemasangan komponen pada PCB sensor cahaya. (3) Guru mengajak siswa melaksanakan pemasangan komponen pada PCB. Kegiatan siswa antara lain: menyiapkan peralatan, komponen, memasang komponen pasif komponen aktif, melakukan penyolderan sampai semua komponen terpasang. Melakukan pengawatan sampai rangkaian dapat berfungsi. (4) Guru mengajak siswa untuk menyiapkan sebuah karya rangkaian berupa rangkaian sensor cahaya, selanjutnya didiskusikan berbagai permasalahanya dalam kelompok. (5) Selanjutnya siswa diminta untuk refleksi secara kelompok untuk mengemukakan permasalahan dan pengalamannya selama mengerjakan pemasangan komponen pada PCB. Guru mengajak siswa untuk mengembangkan diskusi dalam ragka memperbaiki kinerja selaman proses pemasangan komponen pada PCB, sehingga di temukan cara pemasangan komponen yang lebih baik. Pada siklus kedua ini siswa sudah mulai terangsang dan tertantang dalam mengerjakan LKS, kemandirian siswa mulai terlihat dalam mengerjakan LKS. Pada siklus ini terdapat perbedaan aktivitas siswa. Siswa mulai merancang sendiri prosedur praktek, mempersiapkan bahan dan alat secara mandiri.

\section{Tahap Pengamatan}

Pada tahap pegamatan dilaksanakan dengan bantuan teman sejawat ( guru PKWU). Hal yang diamati selama proses pembelajaran berlangsung terekam dalam lembar obervasi meliputi : keterlaksanaan proses pembelajaran dengan Problem Base Learning, aktivitas belajar siswa, kemandirian siswa dalam mengerjakan 
tugas dan prestasi siswa. Hasil pengamatan sebagai berikut:

Data observasi pelaksanaan pembelajaran dengan problem base learning terdapat satu indikator dengan kategori cukup dan enam indikator kategori baik sehingga skor total $=$ $(1 \times 2)+(6 \times 3)=20$ bila skor maksimal 21 maka prosentasenya sebesar $(20 / 21) \times 100 \%=95$, $2 \%$. Dengan melihat tabel 1 maka pelaksanaan pembelajaran kategori baik.

Jumlah skor kemandirin belajar seluruh siswa 2524, jumlah siswa 33 orang maka rerata $=(2524 / 33)=76,6$. berdasarkan tabel 3. rerata kemandirian belajar kategori baik

Skor setiap indikator dari enam kelompok: 12, 17,19, 23, 20, dan 21. Jumlah skor $=112$, jumlah kelompok 6 , skor maksimal 4. Rerata persentase skor aktivitas belajar siswa dalam mengerjakan permasalahan adalah $=\mathrm{x} 100 \%$ $=77 \%$, dengan melihat tabel 2 maka aktivitas belajar siswa kategori baik

Jumlah skor prestasi belajar dari 33 siswa sebesar 2365, maka rerata prestasi belajar $=$ $2365 / 33=71,6$ dengan melihat tabel 4 . kategori baik.

Hasil penelitian siklus kedua seperti tabel 6 .

Tabel 6. Hasil siklus kedua

\begin{tabular}{|c|c|c|c|c|c|}
\hline Siklus & Persentase & & Rerata $S$ & kor & Ket \\
\hline 2 & $\begin{array}{l}\text { pelaksanaan } \\
\text { pembelajaran } \\
95,2\end{array}$ & $\begin{array}{l}\text { aktivitas } \\
\text { belajar } \\
77\end{array}$ & $\begin{array}{l}\text { Karakter } \\
\text { mandiri } \\
76,5\end{array}$ & $\begin{array}{l}\text { Prestasi } \\
\text { belajar } \\
71,6\end{array}$ & meningka \\
\hline Kategori & Baik & Baik & Baik & Baik & \\
\hline
\end{tabular}

\section{Refleksi}

Diskusi dilakukan oleh peneliti dan observer terhadap pelaksanaan pembelajaran siklus II beberapa hambatan dan kekurangan antara lain: (1) Siswa masih menemukan permasalahan dalam merangkai komponen meliputi: kode warna, kode angka, dan cara menguji komponen masih perlu bimbingan. (2) Pemasangan komponen dan menguji rangkaian masih mengalami kesulitan sehingga perlu bimbingan guru. (3) Sudah mulai menggunakan waktu sesuai dengan yang ditentukan. (4) Peran guru mulai berkurang siswa aktif dan mandiri mengerjakan proyek. (5) Hasil pemasangan komponen masih kurang baik walaupun dapat berfungsi. (6) Siswa aktif bertanya pada guru, untuk menyelesaikan proyek. (7) Siswa berani mendiskusikan pengalaman belajarnya selama mengerjakan proyek pada teman dan guru. Guru bersama observer berdiskusi untuk memberikan solusi terhadap permasalahan yang terjadi pada siklus II untuk dilksanakan pada siklus ke III dengan alternatif sebagai berikut : (1) Siswa diajak menjawab permasalahan yang terjadi berkaitan dengan topik merangkai yang meliputi : kode warna, kode angka, cara menguji desain produk dan pengemasan karya rekayasa elektronika praktis. (2) Siswa dimotivasi dengan contoh pemasangan komponen dan menguji rangkaian yang benar. (3) Siswa diajak memanfaatkan waktu dengan tepat. (4) Peran guru sebagai mentor bagi aktivitas siswa perlu dikurangi (5). Hasil proyek harus sesuai dengan stantar ketercapaian, dan berfungsi dengan baik. (6) Siswa dirangsang aktif bertanya saat mengerjakan proyek. (7) Siswa mendiskusikan pengalaman belajarnya selama mengerjakan proyek pada teman dan guru di depan kelas

\section{Siklus III}

Rancangan pada siklus III hampir sama dengan siklus II akan tetapi dilakukan perbaikan - perbaikan rencana tindakan. Pada siklus III ini merupakan kelanjutan dari siklus II sampai hasil proyek terkemas dengan baik. Adapun rencana tindakan yang akan dilaksanakan sebagai berikut:

\section{Perencanaan}

Peneliti menyusun LKS serta instrumen observasi, antara lain : instrumen observasi pembelajaran Problem base learning (PBL), instrumen observasi aktivitas belajar siswa, instrumen kemandirian belajar siswa, instrumen penilaian yang mencerminkan prestasi belajar yang digunakan sebagai catatan selama proses belajar mengajar berlangsung.

\section{Pelaksanaan tindakan dan observasi}

Pelaksanaan pembelajaran pada siklus kedua dilaksanakan pada tanggal 29 Oktober, 
5 dan 12 November 2019 dengan durasi 90 menit ( $2 \times 45$ menit), dengan materi mendesain kemasan sensor cahaya. Pada pertemuan pertama siswa sudah terbiasa dengan situasi kelas yang diamati. Pembelajaran dimulai dengan mengingatkan kembali materi sebelumnya, selanjutnya diberikan motivasi dan membentuk kelompok menjadi 6 kelompok dengan anggota 6 dan 5 orang, diberikan LKS untuk dikerjakan. Tindakan yang dilakukan adalah: (1) Guru mengawali pelajaran dengan penjelasan akan pentingnya kemasan produk elektronika praktis. Kemasan berfungsi untuk pelindung produk dari benturan, cuaca dan memberikan kemudahan membawa. Kemasan memeberikan daya tarik sebagai identitas brand produk. Kemasan didukung oleh material, bentuk, warna, teks dan grafis yang baik. Pemilihan material disesuaikan dengan identitas dan dilengkapi label yang memberikan informasi teknis maupun memperkuat identitas brand. (2) Siswa diarahkan untuk menentukan waktu pengerjaan proyek pembuatan kemasan, waktu yang disepakai proyek ini akan selesai selama 3 minggu ( $3 x$ pertemuan), meliputi desain kemasan pemasangan dan uji coba produk. (3) Guru mengamati capaian kerja proyek setiap minggunya dan mencatat kegiatan siswa selama pembelajaran berlangsung. Guru memfasilitasi siswa dalam setiap proses megerjakan proyek, mendorong siswa untuk melakukan experimen sehingga dapat memecahkan permasalahan dalam pembuatan kemasan produk. (4) Melakukan pengukuran prestasi dengan melihat hasil siswa yang meliputi perencanaan, persiapan, teknik merangkai komponen, keselamatan dalam merangkai dan menguji komponen, bentuk fisik kemasan dan inovasi. Selanjutnya pada pertemuan yang terakhir dilakukan uji coba produk sampai dapat berfungsi dengan baik. Siswa yang belum mampu mendesain kemasan dibimbingan sehingga dapat mendesain. (5) Mengevaluasi kemajuan peserta didik selanjutnya menyusun strategi pada pembelajaran berikutnya, kekurangan dan kelebihannya untuk diperbaiki. siswa diajak diskusi dalam rangka memperbaiki kinerja selama proses pembuatan kemasan produk, sehingga di temukan desain baru yang baik.

Pada siklus ini siswa sudah mulai terbiasa berpikir kritis dalam membuat hipotesis, kemampuan memecahkan masalah, merancang praktikum, menemukan konsep dan menghubungkan konsep mulai terlihat. Setiap LKS siswa dituntut untuk aktif berpikir dan mandiri.

\section{Tahap Pengamatan}

Pengamatan dilaksanakan dengan bantuan teman sejawat ( guru PKWU). Adapun hal yang diamati selama proses pembelajaran berlangsung terekam dalam lembar obervasi yang meliputi : keterlaksanaan proses pembelajaran dengan Problem Base Learning, aktivitas belajar siswa, kemandirian siswa dan prestasi siswa. Hasil pengamatan sebagai berikut:

Data observasi pelaksanaan pembelajaran dengan problem base tujuh indikator kategori baik sehingga skor total $=7 \mathrm{X} 3=21$ bila skor maksimal 21 maka prosentasenya sebesar (21/ 21) $\mathrm{x} 100 \%=100 \%$. Dengan melihat tabel 1 . maka pelaksanaan pembelajaran kategori baik.

Jumlah skor kemandirin belajar seluruh siswa 2910, jumlah siswa 33 orang maka rerata $=(2910 / 33)=88,18$. berdasarkan tabel 3. rerata kemandirian belajar kategori baik.

Skor setiap indikator dari enam kelompok: $14,18,22,22,21$, dan 21. Jumlah skor $=112$, jumlah kelompok 6, skor maksimal 4. Rerata persentase skor aktivitas belajar siswa dalam mengerjakan permasalahan adalah $=\frac{112}{6 \times 4 \times 6} \times 100 \%$ $=81,5 \%$, dengan melihat tabel 2 . maka aktivitas belajar siswa kategori baik

Jumlah skor prestasi belajar dari 33 siswa sebesar 2426 maka rerata prestasi belajar $=$ $2426 / 33=73,5$ dengan melihat tabel 4 . kategori baik.

\begin{tabular}{clllll}
\multicolumn{5}{c}{ Tabel 6. Hasil siklus kedua } \\
\hline Siklus & Persentase & & Rerata Skor & Keterangan \\
\hline \multirow{3}{*}{3} & pelaksanaan & aktivitas & Karakter & Prestasi & \\
& pembelajaran & belajar & mandiri & belajar & \\
& 100 & 81 & 88,18 & 73,5 & meningkat \\
\multirow{2}{*}{ Kategori } & Baik & Sangat & Sangat & Baik & \\
& & Baik & Baik & & \\
\hline
\end{tabular}




\section{Refleksi}

Diskusi peneliti dan observer terhadap pelaksanaan pembelajaran siklus III beberapa kelebihan dan kekurangan antara lain: (1) Secara umum siswa mampu memecahkan permasalahan yang terjadi berkaitan dengan topik mendesain kemasan produk rekayasa. (2) Dalam mengerjakan desain kemasan kreatifitas siswa sudah terlihat di buktikan dengan banyaknya aneka desain kemasan. (3) Penggunaa waktu sudah sesuai dengan yang ditentukan. (4) Guru berperan sebagai mentor, siswa mulai aktif mengerjakan proyek pembuatan desain kemasan.

(5) Hasil desain kemasan, bentuk maupun tampilan sudah baik. (6) Siswa aktif bertanya untuk menyelesaikan proyek. (7) Siswa sudah berani mendiskusikan pengalaman belajarnya selama mengerjakan proyek pada teman dan guru. Terbukti adanya peningkatan pelaksanaan pembelajaran dengan Problem Base Learning, aktivitas belajar siswa, karakter mandiri dan prestasi belajar seperti pada berikut:

Tabel 7. Hasil siklus 3

\begin{tabular}{clllll}
\hline \multirow{2}{*}{ Siklus } & Persentase & \multicolumn{3}{c}{ Rerata Skor } & Keterangan \\
\cline { 2 - 5 } & $\begin{array}{l}\text { pelaksanaan } \\
\text { pembelajaran }\end{array}$ & $\begin{array}{l}\text { aktivitas } \\
\text { belajar }\end{array}$ & $\begin{array}{l}\text { Karakter } \\
\text { mandiri }\end{array}$ & $\begin{array}{l}\text { Prestasi } \\
\text { belajar }\end{array}$ & \\
\cline { 1 - 5 } 1 & $90,4 \%$ & $69 \%$ & 73,06 & 65,57 & meningkat \\
2 & $95,2 \%$ & $77 \%$ & 76,5 & 71,6 & \\
3 & $100 \%$ & $81 \%$ & 88,18 & 73,5 & \\
\hline
\end{tabular}

\section{PEMBAHASAN}

Hasil penelitian yang telah diuraikan di atas dapat diketahui bahwa pembelajaran PKWU dengan menggunakan model Problem base Learning (PBL) dapat diuraikan sebagai berikut:

Metode Problem Base Learning (PBL) terbukti dapat meningkatkan aktivifitas belajar siswa dalam memecahkan masalah di kelas XII IPS 2, seperti pada grafik berikut.

Terlihat bahwa aktivitas belajar siswa mengalami kenaikan dari siklus I sebesar 69 dengan kategori baik, kemudian pada siklus II sebesar 77 dengan kategori baik dan di akhir siklus III menjadi 81 dengan kategori sangat baik. Ini sejalan dengan

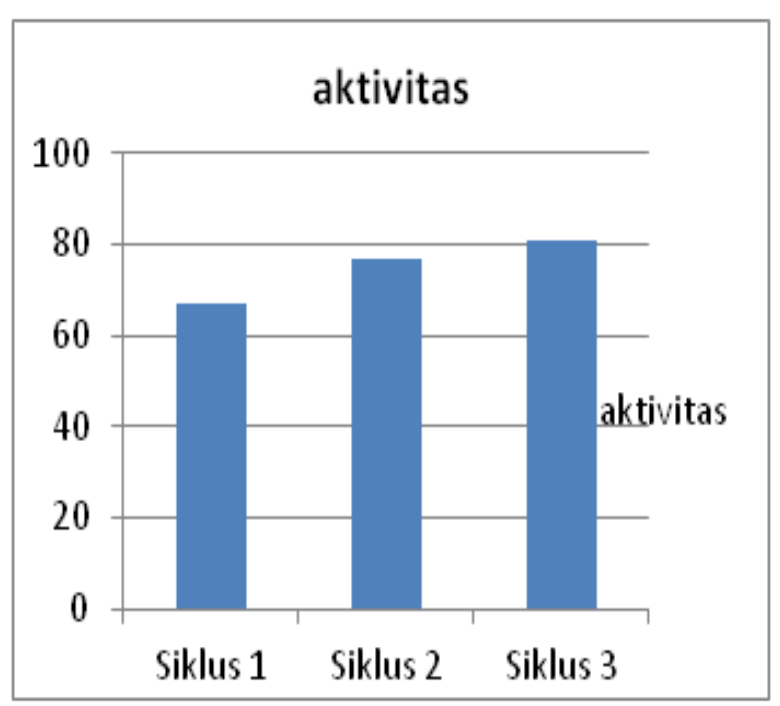

Gambar 1. Grafik aktivitas belajar

hasil penelitiaan Prasetya (2011), bahwa dengan menggunakan metode problem base learning dapat meningkatkan aktivitas siswa dalam memecahkan masalah. Model PBL mampu meningkatkan aktivitas belajar siswa, terbukti pada aktivitas mendengarkan ini akan nampak setelah guru menjelaskan materi pembelajaran dan siswa mendengarkan. Pada tahap mengidentifikasi permasalahan terlihat siswa disibukkan menulis permasalahan yang terjadi. Pada tahap merumuskan masalah akan nampak setelah siswa selesai melakukan masalah. Masalah yang telah dirumuskan siswa, dicari solusi penyelesaiannya melalui aktivitas menyimak handout. Siswa mencari informasi tentang topik permasalahan, informasi yang diperoleh siswa dianalisis guna penyusunan laporan solusi permasalahan. Pada aktivitas ini sudah nampak aktivitas pemecahan masalah. Siswa menyusun laporan hasil analisis informasi, selanjutnya dipresentasikan di depan kelas secara berkelompok. Kelompok lain yang mendengarkan memberikan tanggapan atau pendapatnya atas laporan yang disampaikan kelompok lain. Siswa bersama guru merefleksi kegiatan PBL, guru bertanya seputar kegiatan pembelajaran yang telah siswa alami.

Metode Problem Base Learning (PBL) terbukti dapat meningkatkan prestasi belajar siswa di kelas XII IPS 2, seperti pada grafik berikut. 


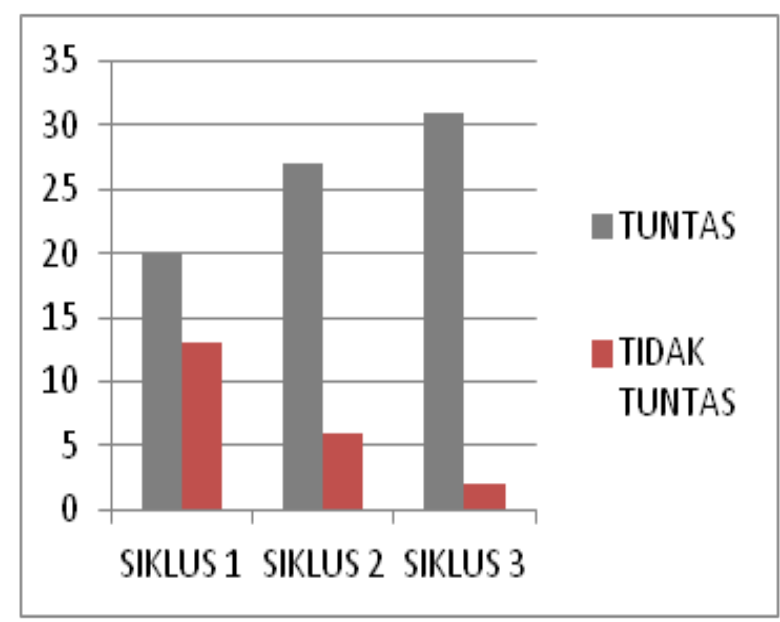

Gambar 2.Grafik Prestasi belajar

Terlihat terjadi peningkatan prestasi belajar, pada siklus I siswa yang tuntas belajar sebesar 19, siklus II sebesar 23 dan pada siklus II sebesar 30 siswa. Rerata skor prestasi siswa juga mengalami peningkatan yaitu siklus I sebesar 65,57, siklus II sebesar 71,66 dan siklus III 73,5 .

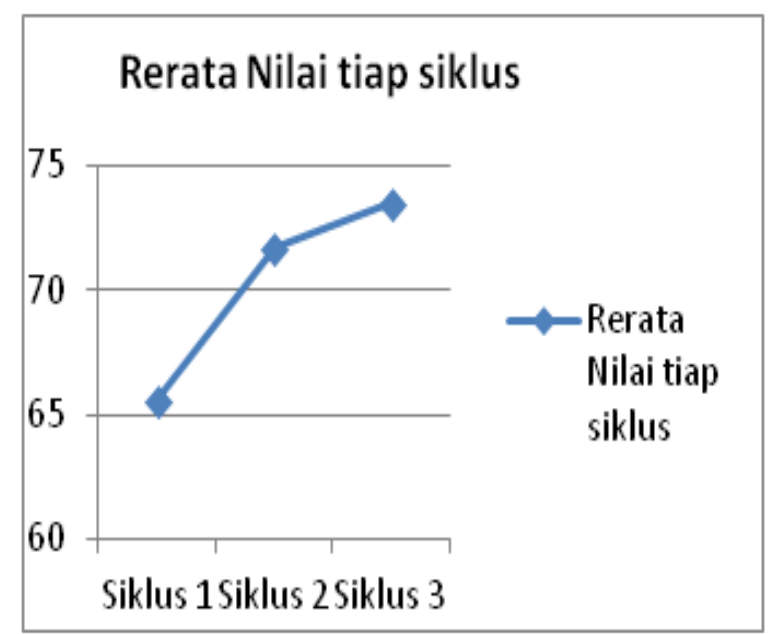

Gambar 3.Grafik rerata nilai

Dari grafik dapat disimpulkan bahwa dengan mengunakan metode Problem Base Learning (PBL) proses mengerjakan proyek desain produk dan pengemasan karya rekayasa elektronika praktis, mengalami peningkatan. Artinya pada siklus pertama siswa mampu mengerjakan proses desain rangkaian rangkaian sampai tercetak PCB. Dilanjutkan pada siklus kedua siswa mampu mengerjakan proses perakitan komponen, pengawatan dan pengujian. Pada siklus ketiga ini siswa mampu men gerjakan pengemasan produk sampai produk dapat di pakai dan dipasarkan. Model PBL memberikan kesempatan siswa untuk mengembangkan sikap ilmiah yaitu keterampilan proses sain saat pembelajaran berlangsung, keterampilan proses sain yang baik akan menghasilkan prestasi belajar yang baik pula.

Metode Problem Base Learning (PBL) terbukti dapat meningkatkan karakter mandiri siswa, seperti terlihat pada grafik berikut.

Hal ini terlihat dari skor karakter mandiri yang diperoleh siswa pada siklus I, siklus II dan siklus III. Rerata karakter mandiri pada siklus I sebesar 73,08, pada siklus II sebesar 76,51, dan pada siklus III sebesar 88,18. Pada Metode PBL ini siswa terbiasa berkomunikasi, menyiapkan bahan dan alat, mengajukan pertanyaan dan hipotesis, berdiskusi dan presentasi di depan kelas sehingga kemandirian siswa terlihat naik pada setiap siklusnya.

Pembelajaran PKWU dengan menggunakan model model Problem Base Learning (PBL) telah dilaksanakan guru pada siklus I sebesar 90,4\%, pada siklus II sebesar $95,2 \%$ dan pada siklus III sebesar $100 \%$. Mengandung artinya bahwa langkah-langkah pembelajaran dengan metode Problem Base Learning (PBL) telah dilaksanakan guru pada akhir siklus III.

Dari pembahasan diatas dapat disimpulkan bahwa dengan menggunakan metode Problem

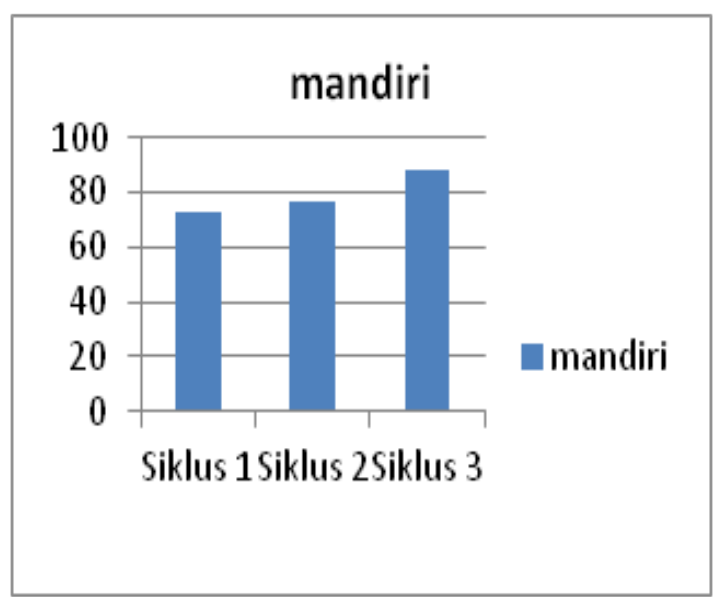

Gambar 4.Grafik karakter Mandiri 
Base Learning (PBL) dapat meningkatkan prestasi belajar dan kemandirian belajar siswa kelas XII IPS 2. Sejalan dengan pendapat Mely (2018), bahwa metode Problem Base Learning (PBL) berpengaruh signifikan terhadap hasil belajar. PBL bertujuan untuk membantu memperlancar jalannya kegiatan pembelajaran yang terdiri dari tujuan pembelajaran, masalah, lembar diskusi, lembar praktikum, tugas mandiri, analisis dan evaluasi, serta latihan soal. Pemberian masalah dalam LKS akan merangsang siswa untuk mengembangkan keterampilan proses sains siswa. LKS berbasis PBL harus dikerjakan secara bersama agar kegiatan pembelajaran menjadi lebih terstruktur serta dapat meningkatkan kerjasama dan tanggung jawab siswa dalam menentukan konsep pembelajaran. Pembelajaran problem based learning juga lebih merangsang dan menantang siswa dalam pembelajaran, mendorong siswa untuk mandiri dalam menetapkan tujuan pembelajaran. Penerapan model problem based learning membiasakan siswa untuk berpikir kritis dalam membuat hipotesis untuk memecahkan masalah, merancang percobaan, menemukan konsep, dan menghubungkan konsep dengan kehidupan sehari-hari. Setiap proses pembelajaran siswa selalu dituntut untuk aktif berpikir, memiliki kelebihan dalam penyajian masalah yang terdapat pada LKS. Siswa dengan penuh rasa

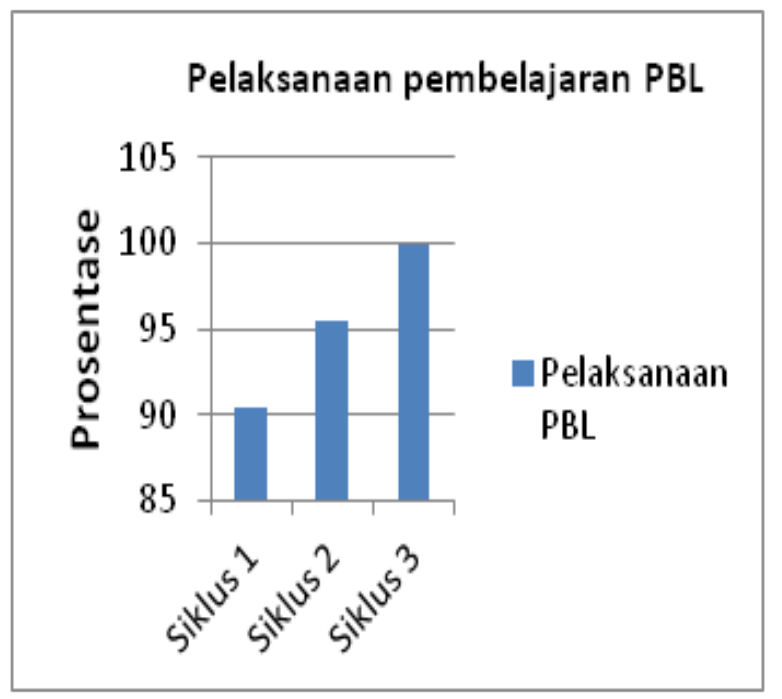

Gambar 5. Grafik pelaksanaan PBL ingin tahu menyelesaikan masalah dengan mencari referensi untuk menjawab pertanyaanpertanyaan yang tersedia dalam LKS agar hipotesis yang disusun dapat terbukti.

\section{KESIMPULAN}

Berdasarkan hasil penelitian dan pembahasan dapat disimpulkan bahwa:

Metode problem based learning dapat meningkatkan prestasi belajar siswa pada mata pelajaran Prakarya dan Kewirausahaan (PKWU) di kelas XII IPS2 MAN 1 Kulon Progo.

Metode problem based learning dapat meningkatkan kemandirian belajar siswa pada mata pelajaran Prakarya dan Kewirausahaan (PKWU) di kelas XII IPS2 MAN 1 Kulon Progo

\section{DAFTAR PUSTAKA}

Budi, S (2012). Korelasi antara Kreativitas, Motivasi, dan Kemandirian belajar siswa dengan prestasi belajar, Jurnal Insight. Vol 10 No 1 UMBY, Yogyakarta.

Budi,S, (2012). Korelasi Antara Kreativitas Belajar, Motivasi Belajar Dan Kemandirian Belajar Siswa Dengan Prestasi Belajar Keterampilan Elektronika Di MAN I Wates Kabupaten Kulon Progo Tahun 2012. Thesis Yogyakarta: Universitas Mercu Buana Yogyakarta

Budi,S. (2014). Penerapan Metode Problem Based Instruction (PBL) untuk meningkatkan kemampuan siswa dalam memecahkan masalah keterampilan elektronika di kelas XI IPA1 MAN Wates I Kabupaten Kulon Progo. PTK Yogyakarta,

Djamarah, S 1994. Prestasi Belajar dan Kompetensi Guru. Usaha Nasional, Surabaya

Febriana,R \& Sarbiran, 2001. Pengaruh kemandirian dan kemampuan menyesuaikan diri terhadap prestasi belajar siswa full day school. Jurnal penelitian dan evaluasi No.4 tahun Ke3. Yogyakarta:Pascasarjana Universitas Negeri Yogyakarta. 
https://nasional.tempo diakses tanggal 10 Desember 2019

http://alief-hamsa.blogspot.com/2009/08/ perubahan- paradigma-pendidikan-di. $\mathrm{html}$ [tersedia online] diakses tanggal 9 Desember 2020.

Prasetyo, H (2011), Penerapan Model Problem Base Instruction untuk meningkatkan kemampuan memecahkan masalah matematika pada pkok bahasan bangun ruang sisi lengkung
Rusmono, (2017). Strategi pembelajaran dengan Problem Base Learning itu perlu. Ghalia Indonesia, Jakarta

Team Kurikulum,(2018). Kurikulum KTSP MAN 1 wates tahun 2017/2018: Yogyakarta

Zulharman. (2007). Problem Based Learning (PBL) (online) http://zulharman79. wordpress.com/2007/07/15/problembased-learning-pbl/ (diakses 10 Desember 2019).

di kelas XI H SMP 2 Majenang. Skripsi. Yogyakarta :UNY 